\title{
A prática profissional do agente comunitário de saúde: contradições e desafios
}

\author{
Gisele Roberta Nascimento, Beatriz Santana Caçador, Maria José Menezes Brito, Ariadne Barbosa
} do Nascimento Einloft, Ana Paula Mendes dos Santos, Ramon Augusto Ferreira de Souza

\section{Resumo}

O desafio de se transformar o agir em saúde a partir de uma reconfiguração das práticas profissionais e do processo de trabalho em saúde, destaca-se a prática profissional do ACS. Assim, este estudo tem por objetivo compreender a visão do ACS sobre sua prática profissional. O estudo de natureza qualitativa, foram sujeitos 14 ACS's que atuam no interior de Minas Gerais. Para coleta de dados, foi realizada entrevista com roteiro semiestruturado, durante o mês de julho de 2015. Os dados foram transcritos na íntegra e analisados por meio da técnica de Análise de Conteúdo proposto por Bardin. O projeto de pesquisa foi submetido à apreciação do Comitê de Ética e Pesquisa da Universidade Federal de Viçosa e aos participantes foi entregue o Termo de Consentimento Livre e Esclarecimento (TCLE). Diante da análise temática emergiram 3 categorias de análise que são elas: A prática profissional do Agente Comunitário de Saúde: entre o prescrito e o real; O Ministério da Saúde preconiza as atribuições dos profissionais da equipe de saúde da família dentre elas as do ACS. Partindo desse pressuposto, as falas dos participantes da pesquisa revelam coerência entre a percepção sobre seu papel profissional e as atribuições previstas pela política de saúde brasileira. No que diz respeito ao distanciamento entre as atribuições preconizadas e a prática realizada pelo ACS, foi possível perceber que o desenho organizacional fortalece esse distanciamento ao deliberar como função do ACS práticas que não são de sua competência profissional e cujo objetivo é suprir lacunas do sistema. ACS: os laços de identificação. A prática profissional permite refletir sobre os laços de identificação que o profissional estabelece com seu trabalho, e também, sua identificação organizacional. Esta é um alicerce para o pertencimento do indivíduo ao seu trabalho e para a construção de sua identidade profissional Pagés (1987) apud Alves (2007). Assim, no contexto da prática profissional dos ACS's deste estudo, foi possível perceber a presença de laços afetivos e ideológicos, materiais-econômicos e profissionais. Há que se ressaltar que o estabelecimento de vínculos organizacionais não garante, necessariamente, que os objetivos sejam sempre alcançados. O desafio da formação do Agente Comunitário de Saúde: a gente aprende na marra. Muitos são os debates em torno do perfil e competência profissional do ACS, mas não há consenso na literatura no que tange a uma delimitação clara e efetiva do escopo de sua prática. O que existe é uma referência explícita ao ACS como sendo o protagonista de um novo perfil profissional na saúde. Entretanto, não há uma especificação delimitada do que seria esse novo perfil e essa nova prática. O estudou permitiu compreender a percepção dos ACS's sobre sua prática profissional, evidenciando as contradições e os desafios desse fazer. Podemos inferir que embora seja preconizada pelo Ministério da Saúde, sofre influências do contexto local sendo reconfigurada por meio dos arranjos organizacionais de cada município. Os ACS's deste estudo compreendem as atribuições que lhes são previstas pela política de saúde, mas não encontram condições para efetivá-las no cotidiano dos serviços.

Descritores: Enfermagem; Agentes Comunitários de Saúde; Prática Profissional. 